\title{
HONEYBEE CHITOSAN-MELANIN COMPLEX: ISOLATION AND INVESTIGATION OF ANTIMICROBIAL ACTIVITY
}

\author{
M. LOOTSIK 1, N. MANKO 1 , O. GROMYKO', \\ S. TISTECHOK ${ }^{2}$, M. LUTSYK (Jr. $)^{3}$, R. STOIKA ${ }^{1 凶}$ \\ ${ }^{1}$ Institute of Cell Biology, National Academy of Sciences of Ukraine, Lviv; \\ ${ }^{2}$ Ivan Franko National University of Lviv, Ukraine; \\ ${ }^{3}$ Danylo Halytsky Lviv National Medical University, Ukraine; \\ 凶e-mail: stoika.rostyslav@gmail.com
}

Received: 4 May 2020; Accepted: 13 November 2020

\begin{abstract}
Antimicrobial activity of marine crustaceans chitosans is well studied and is widely used in medicine, while chitosans of insects are poorly investigated in this aspect, though they might also be of practical significance. The aim of this study was to isolate and purify chitosan-melanin complex (CMC) from the honeybee corpses and to estimate its antimicrobial activity. Antibacterial activity of CMC was evaluated by MTT test, antifungal activity towards Candida albicans was estimated by calculating colony forming units (CFU method). The modified method of CMC isolation and purification was described which differs from the known analogs in deacetylation of chitin-melanin complex by its hydrolysis in $40 \% \mathrm{NaOH}$ without previous melanin elimination and in further purification of CMC by differential solubilization at distinct $\mathrm{pH}$ values. The antimicrobial activity of $C M C$ was characterized by prevalence of candidacidal effect, $I C_{50}$ towards laboratory strain of C. albicans was $50 \mu \mathrm{g} / \mathrm{ml}$. The ranking of studied bacteria sensitivity to the CMC action decreased as: E. coli > St. aureus > Ps. aeruginosa. It is suggested that CMC isolated from the honeybee corpses might be a perspective constituent of medicinal compositions for treatment of lesions caused by C. albicans infection.
\end{abstract}

Ke y w ord s : chitosan-melanin complex, honeybee corpses, MTT test, antimicrobial activity.

$\mathrm{T}$ he antimicrobial activity of chitosan and its derivatives obtained from marine crustaceans is well investigated and documented $[1,2]$. This property of chitosan is widely used in dressing materials for healing wounds and burns [3], the comprehensive information up to 2011 year see in excellent review by Dai T. et al. [2]. Further investigations were devoted to an enhancement of the antimicrobial activity of chitosan or its fragments by their complexation with different antimicrobial agents, including nanoparticles, and via an improvement of water solubility of their preparations in neutral or weak alkaline media [4-8].

Biological, specifically the antimicrobial activity of chitosan isolated from the honeybee (Apis mellifera), is much less investigated, compared to chitosans obtained from marine crustaceans though it might also have a practical significance $[9,10]$. The available publications devoted to isolation and purification of chitin/chitosan from insect sources were addressed mainly to investigation of physicochemical properties of the obtained products [9-13]. The information on the biological effects of the honeybee chitosan and chitosan-melanin complex (CMC) is rather scarce [14-16]. It was shown that $\mathrm{CMC}$ from the honeybees effectively absorbs watersoluble compounds of the radionuclides ${ }^{90} \mathrm{Sr}$ and ${ }^{233} \mathrm{U}$ from their solutions [14]. A method of isolation the CMC from the honeybee corpses and a description of its application as a dietary supplement in fattening of calves were provided in the patent of the Russian Federation [10]. Paper devoted to preparation of chitosan from the honeybees (entitled Beetosan ${ }^{\mathrm{R}}$ ) and to the biological effects of the hydrogels combined with the bioactive compounds of plant origin have been published [17].

The formation of complex with melanin in insect cuticle is a characteristic property of the hon-

(C) 2020 Lootsik M. et al. This is an open-access article distributed under the terms of the Creative Commons Attribution License, which permits unrestricted use, distribution, and reproduction in any medium, provided the original author and source are credited. 
eybee chitin/chitosan. The elimination of melanin during the purification process is usually achieved by the treatment of chitomelanin with strong oxidants (hydrogen peroxide, potassium permanganate, sodium hypochlorite), however, it is difficult to predict their influence on the biological activity of final product [9-13]. In our studies, we revealed that melanin did not affect the antimicrobial activity of the honeybee chitosan $[15,16]$ and its elimination can be omitted in a process of chitosan purification, thus, chitosan-melanin complex (CMC) can be obtained as a final product

The aim of present study was to optimize the method of isolation and fractionation of chitosanmelanin complex from the honeybee corpses, and to characterize properties of the product including its effect upon the viability of selected bacteria and fungi.

\section{Materials and Methods}

Chitosan-melanin complex (CMC) was prepared from the honeybee corpses obtained during 2015-2019 in local apiaries of Lviv region. The procedure of isolation and fractionation is described in the "Results and discussion" section.

Peptone (enzymatic, Institute of provisions resources, NAAS of Ukraine, Kyiv) and glucose (Fufen, China) as components of Sabouraud medium, agar (microbiological quality, Spain), dimethylsulfoxide (DMSO, LAB-SCAN, Ireland) were purchased from Sfera 7 (Lviv, Ukraine). The MTT reagent (thiazolyl blue) was purchased from SigmaAldrich (St. Louis, MO, USA).

The Kit of reagents for electrophoresis in the polyacrylamide gel was purchased from "Reanal", Hungary. Electrophoresis of CMC and chitosan was conducted in the polyacrylamide gel with a stepwise gradient of the acrylamide concentration - 5, 10, 15, $20 \%$, as described in $[18,19]$. The densitometric profile of electrophoregrams (plots) and quantitative evaluation of bands intensity was performed using “Image J” program.

$\mathrm{NaOH}, 25 \%$ ammonium hydroxide, acetic acid and other chemicals were of the reagent grade quality and purchased from Sfera 7 (Lviv, Ukraine). The glycolic acid of the reagent grade quality was purchased from "UkrOrgSynthesis” (Kyiv, Ukraine).

The following microorganisms were used as targets of CMC effect: S. aureus ATCC 25923, E. coli dH5 $\alpha$, Ps. aeruginosa ATCC 9027, two C. albicans strains - a laboratory strain ATCC 885-
655 and drug resistant strain N 12. The microbial cultures were obtained from the collection of the Department of Genetics and Biotechnology, Ivan Franko National University of Lviv.

Experiments on antimicrobial activity of CMC were performed in the Sabouraud medium at $\mathrm{pH} 5.8$ and 7.2 in order to compare the effect of $\mathrm{pH}$ upon CMC activity towards fungi and bacteria cultivated in close conditions.

Antibacterial activity was determined using the MTT test [20, 21]. Preparation of bacterial suspension in media with different $\mathrm{pH}$ values was conducted as follows. Subsequent bacterial culture in the logarithmic phase of growth in Sabouraud medium, $\mathrm{pH}$ 7.2, was centrifuged $10 \mathrm{~min}$ at 1,000 g, bacteria sediment was washed with sterile saline and re-suspended in $0.5 \mathrm{ml}$ of sterile saline. A defined volume of this suspension was introduced into Sabouraud medium with different $\mathrm{pH} 5.8$ or 7.0 up to the achievement of OD at $600 \mathrm{~nm}$ 0.4-0.6 (optical path $1.0 \mathrm{~cm}$ ). $100 \mu \mathrm{l}$ of each suspension were introduced into series of $2 \mathrm{ml}$ Eppendorf tubes, and thereafter, 10,5 and $2.5 \mu 1$ solution of tested CMC sample were inoculated (preparation of CMC solutions is shown below). Each point was repeated in triplicate. The tubes were incubated for $4 \mathrm{~h}$ at $37^{\circ} \mathrm{C}$. Thereafter, $10 \mu \mathrm{l}$ of the MTT solution $(5 \mathrm{mg} / \mathrm{ml})$ was introduced, and the incubation was continued for $1 \mathrm{~h}$. Cells were harvested by centrifugation ( $5 \mathrm{~min}$ at $1,500 \mathrm{~g}$ ), supernatant was discarded, and small sediment was suspended in $1 \mathrm{ml}$ of the DMSO. After the incubation for $1 \mathrm{~h}$ at $37^{\circ} \mathrm{C}$, the OD of liquid was measured at $580 \mathrm{~nm}$ in the ULAB 102 UV spectrophotometer, (Ukraine). The effect of CMC upon bacteria was expressed as a percentage ratio of the OD in experimental to control probes calculated by the formula: $(\mathrm{OD}$ of the probe/OD of control) $\times 100 \%$.

Antifungal activity was studied on C. albicans strains by the CFU method using the Sabouraud medium. The quality of peptone as the component of the Sabouraud medium and control of $\mathrm{pH}$ are of great importance for the reproducibility of results. We used in the experiments the enzymatic peptone (Kyiv, Ukraine) that provided a rapid growth of C. albicans and the appearance of distinct colonies after $24 \mathrm{~h}$ of incubation at $37^{\circ} \mathrm{C}$.

A suspension of Candida sp. containing $10^{7}$ cells/ml was prepared by suspending cells taken from the colonies grown on the Sabouraud agar, pH 5.8. Cell number was counted in Horyaev hemocytometric camera, since a size of Candida cells 
(2.5-4 $\mu \mathrm{m})$ permitted doing that accurately. The tested CMC solution in 10,5 and $2.5 \mu$ volume was introduced into 3 round bottom Eppendorf tubes, and thereafter, $100 \mu 1$ of Candida cells suspension was added. Two control tubes were prepared: at the start (time 0 ) and at the end ( $4 \mathrm{~h})$ of incubation. The tubes were incubated for $4 \mathrm{~h}$ at $37^{\circ} \mathrm{C}$ (except control 0 kept at $4^{\circ} \mathrm{C}$ ). $10 \mu \mathrm{l}$ aliquot was withdrawn at the end of incubation from each tube after thorough mixing, diluted 10,000 fold with water and $0.2 \mathrm{ml}$ of this dilution was distributed on the surface of Sabouraud agar medium, $\mathrm{pH}$ 5.6, in the Petri dish. They were incubated at $37^{\circ} \mathrm{C}$ and after distinct formation of colonies (usually after $24 \mathrm{~h}$ ) the image was scanned and colonies were counted with the aid of the Photoshop program. The number of colonies in control tube at $0 \mathrm{~h}$ time must be $200 \pm 50$ per dish, in control after $4 \mathrm{~h}$ of incubation colonies number must be 1.5-2.5 fold higher. The experiment was abolished when the increase in number of colonies in control after the incubation was less then 1.5 fold. The effect of CMC sample upon the viability of Candida cells was expressed as a percentage ratio of colony number in experimental to control (time 0) probes, calculated by the formula: [(number of colonies in experimental tubes)/(number of colonies in control (at time 0$))] \times 100 \%$.

The index lower than $100 \%$ was considered as candidacidal effect, while higher than $100 \%$ but less than in control after $4 \mathrm{~h}$ of incubation was classified as growth inhibition, and higher than in control after $4 \mathrm{~h}$ of incubation indicated a stimulation of growth.

Preparation of CMC solutions for testing of antimicrobial activity. Transformation of chitosan or CMC solid powder to a gel form is desirable in order to facilitate the preparation of solutions at desired conditions. A distinct quantity of the CMC was dissolved in $0.5 \mathrm{M}$ acetic acid to a concentration 1-2\% under a constant stirring during 10-12 h, and the obtained solution was adjusted to $\mathrm{pH}$ 8.5-9.0 with $10 \%$ ammonium hydroxide. Sediment was collected by centrifugation (10 $\mathrm{min}$ at $1,500 \mathrm{~g}$ ) and washed 2 times with distilled water. The content of solid residue in the obtained gel was determined gravimetrically by weighting small aliquot of wet material and after its drying for $1 \mathrm{~h}$ at $105^{\circ} \mathrm{C}$. The gel can be stored in a closed vessel for 1 month at $4^{\circ} \mathrm{C}$.

CMC solution was prepared by suspending aliquot of wet gel corresponding to $4 \mathrm{mg}$ of dry material in $1.5 \mathrm{ml}$ of distilled water and homogenized by a repeated passing of suspension through a syringe with suitable needle. Thereafter, suspension was adjusted to $\mathrm{pH} 5.6$ with $0.5 \mathrm{M}$ acetic acid or glycolic acid under the control of $\mathrm{pH}$ meter. The volume of solution was adjusted to $2 \mathrm{ml}$ and left for $5-6 \mathrm{~h}$ at $20^{\circ} \mathrm{C}$. The solution was transferred to 3 small tubes, which were sealed and heated in the water bath for $15-20 \mathrm{~min}$ at $80^{\circ} \mathrm{C}$. The solution was stored no more than 2-3 weeks at $4^{\circ} \mathrm{C}$.

Average molecular mass and hemocoagulating activity of CMC samples were determined, as described [18].

Determination of CMC hemagglutination titer was performed in $\mathrm{pH} 6.0$ saline as solvent providing a sufficient stability of the diluted solutions of CMC. The working solution of CMC in concentration $200 \mu \mathrm{g} / \mathrm{ml}$ was prepared by dilution of a stock solution $(2 \mathrm{mg} / \mathrm{ml}$ ) with saline, $\mathrm{pH} 6.0$ (buffered with $0.01 \mathrm{M}$ acetate buffer). A line of 2-fold dilutions of the CMC solution in 12 glass tubes $(25 \times 5 \mathrm{~mm}$ inner diameter) was prepared by a known manner leaving $50 \mu \mathrm{l}$ of solution in each tube. $50 \mu 1$ of $2 \%$ suspension of human red blood cells was introduced into each tube and incubated for $15 \mathrm{~min}$ at $20^{\circ} \mathrm{C}$ and centrifuged at $200 \mathrm{~g}$ for $30 \mathrm{sec}$. Agglutination of red blood cells was registered visually after a gentle shaking of the tube. The titer of the hemagglutination corresponded to the minimal concentration of CMC which induced agglutination of the red blood cells.

Statistical analysis. The data are presented as the Mean \pm SD. The significance of difference between compared data was analyzed by Student's $t$ test using Graph Pan Prism 6 program. Levels of significance of differences were signed with asterisks: * $P<0.05, * * P<0.01, * * * P<0.001$.

\section{Results and Discussion}

To isolate and purify the honeybee CMC, we have modified the method that was previously developed in our laboratory for isolation of honeybee chitosan [19]. The initial stages of treatment of insect material were saved and included:

1) devitalization (repeated washing of the material with boiling water);

2) delipidation (extraction of dry powdered material with petrol ether);

3) decalcification (treatment of powder with EDTA at pH 4.0); 4) deproteination (repeated treatment with $5 \% \mathrm{NaOH}$ at $70^{\circ} \mathrm{C}$ ). However, the treatment of material with sodium hypochlorite (strong oxidant) for elimination of melanin was omitted 
and the obtained chitin-melanin complex was deacetylated by hydrolysis in $40 \% \mathrm{NaOH}$ at $115^{\circ} \mathrm{C}$ in a pressure-cooker for 90-150 min (this time varied in dependence on the desired properties of the product).

The hydrolysate was cooled and diluted with 2 volumes of distilled water and centrifuged for $20 \mathrm{~min}$ at 2,500 g. Sediment was suspended in the distilled water and $\mathrm{pH}$ adjusted to 10.0 with a glacial acetic acid. Sediment was collected by centrifugation for $20 \mathrm{~min}$ at 2,500 $\mathrm{g}$ and washed twice with the distilled water. Thereafter, it was suspended in 5 volumes of $0.5 \mathrm{M}$ solution of the acetic acid and stirred for 3-9 h by the mechanical stirrer for dissolution of the CMC. The mixture was centrifuged for $30 \mathrm{~min}$ at 2,500 g, the supernatant was saved, and sediment was treated once more with 3 volumes of $3 \%$ acetic acid, the mixture was centrifuged and both supernatants were combined. The dissolved CMC was precipitated by the adjustment to $\mathrm{pH}$ 8.5-9.0 with $20 \%$ ammonium hydroxide (homogenization is needed for pellets disaggregation). The mixture was kept for $4 \mathrm{~h}$ at $4^{\circ} \mathrm{C}$ and then it was centrifuged for $10 \mathrm{~min}$ at $1,200 \mathrm{~g}$. The sediment of the CMC was collected and washed twice with the distilled water, and the obtained material was defined as raw $\mathrm{CMC}$, the yield was $6.9 \%$ of the initial mass of material taken for hydrolysis.

The fraction insoluble in $0.5 \mathrm{M}$ acetic acid was adjusted to $\mathrm{pH} 9$ with $20 \%$ ammonium hydroxide, which led to 10 -fold decrease of volume. The sediment was collected by filtration through a polyamide cloth as filter material, washed with distilled water, ethanol, and then dried in a thin layer at $20-25^{\circ} \mathrm{C}$. The yield of this fraction was $18.6 \%$ of the mass of material taken for hydrolysis. Later on, this fraction was subjected to repeated hydrolysis in $40 \% \mathrm{NaOH}$.

Soluble fraction of the CMC was further purified by differential solubilization at distinct $\mathrm{pH}$ values. Raw CMC was suspended in 3 volumes of the distilled water and homogenized using PotterElvehjem homogenizer by multiple strikes of pestle. The suspension was adjusted to $\mathrm{pH} 7.2$ with $0.5 \mathrm{M}$ solution of acetic acid, stirred for $3 \mathrm{~h}$ and centrifuged for $20 \mathrm{~min}$ at 2,500 g. The supernatant was collected and retained, while the sediment was washed with 2 volumes of distilled water at $\mathrm{pH} 7.2$, centrifuged for $20 \mathrm{~min}$ at 2,500 g, and the supernatant was combined with the first portion and stored at $4^{\circ} \mathrm{C}$.

Washed sediment was homogenized in 3 volumes of the distilled water and adjusted to pH 4.8-5.0 with $0.5 \mathrm{M}$ acetic acid. The mixture be- came viscous and more distilled water was added in order to achieve a moderate viscosity. Mixture was stirred for $6 \mathrm{~h}$ or kept for $12 \mathrm{~h}$ at room temperature, thereafter, centrifuged for $30 \mathrm{~min}$ at 2,500 g. The supernatant was collected and saved, while the sediment was extracted once more by its suspending in the distilled water at $\mathrm{pH}$ 5.0, and then kept for $6 \mathrm{~h}$ at room temperature with an occasional stirring. The mixture was centrifuged for $30 \mathrm{~min}$ at 2,500 g, the supernatant was collected and combined with the previous portion, and a small sediment was saved and defined as fraction insoluble at $\mathrm{pH}$ 5.0.

Three fractions of the CMC were obtained by the differential solubilization: a) fraction soluble at pH 7.2 (about $10 \%$ of material), b) fraction soluble in $\mathrm{pH}$ range of 5.0-7.0 (about 70\% of material), c) insoluble fraction at $\mathrm{pH} 5.0$ (about $20 \%$ of the material). These fractions were transformed to alkaline form by an adjustment of solution or water suspension to $\mathrm{pH}$ 8.5-9.0 with 5\% ammonium hydroxide. The sediments were collected by centrifugation for $10 \mathrm{~min}$ at $1,200 \mathrm{~g}$, washed twice with distilled water and stored at $4^{\circ} \mathrm{C}$. The content of dry residue in fractions was determined gravimetrically.

Taking into account that the glycolic acid is stronger and more hydrophilic than the acetic acid, two salt forms of the CMC fraction "b" were obtained - acetate salt and glycolate salt. They were prepared by suspending of a weighted amount of fraction "b" gel with a known content of dry material in 2 volumes of the distilled water and homogenization by a multiple passing through syringe with a needle of suitable size. The suspension was adjusted to $\mathrm{pH}$ 5.3-5.4 with $0.5 \mathrm{M}$ solution of the acetic acid or glycolic acid added in small portions under a control of $\mathrm{pH}$ meter and homogenization after each addition. A viscous mixture was left for several hours at room temperature and then diluted with distilled water to desired concentration of the CMC according to a known quantity of taken dry substance. Optionally, the mixture was poured onto a glass plate and dried by the evaporation. Dry film was harvested and grinded to powder. Some properties of the obtained honeybee CMC are described in Table 1. One can see that fractions soluble in more alkaline $\mathrm{pH}$ are of significantly lower molecular mass, contain less melanin and exhibit lower hemagglutinating and hemocoagulating activity. An important feature is that the glycolate salt of the CMC demonstrated higher hemocoagulating activity than the acetate salt did. 
Ta ble 1. Properties of chitosan-melanin complex and its fractions

\begin{tabular}{|c|c|c|c|c|}
\hline \multirow[b]{2}{*}{ Property } & \multicolumn{4}{|c|}{ Designation of chitosan-melanin complex fractions } \\
\hline & $\begin{array}{c}\text { Soluble } \\
\text { in } 0.5 \mathrm{M} \\
\text { acetic acid }\end{array}$ & $\begin{array}{c}\text { Soluble in } \\
\text { pH 5.0-7.0 } \\
\text { (acetate anion) }\end{array}$ & $\begin{array}{l}\text { Soluble in } \\
\text { pH 5.0-7.0 } \\
\text { (glycolate } \\
\text { anion) }\end{array}$ & $\begin{array}{l}\text { Soluble in } \\
\text { pH 7.0-8.6 }\end{array}$ \\
\hline Average molecular mass (kDa), $n=3$ & $186.7 \pm 17.6$ & $223.3 \pm 25.2$ & $228.3 \pm 22.5$ & $110.7 \pm 15.0^{* *}$ \\
\hline Content of melanin (\%), $n=3$ & $15.6 \pm 1.4$ & $12.3 \pm 1.1^{*}$ & $11.7 \pm 0.9^{*}$ & $9.3 \pm 0.8^{* *}$ \\
\hline $\begin{array}{l}\text { Time of blood coagulation, } \\
\text { outset/end (sec) }\end{array}$ & $90 / 150$ & $100 / 150$ & $60 / 120$ & $120 / 210$ \\
\hline Hemagglutinating activity $(\mu \mathrm{g} / \mathrm{ml}), n=3$ & $1.04 \pm 0.45$ & $1.04 \pm 0.45$ & $1.04 \pm 0.45$ & $4.17 \pm 1.80^{*}$ \\
\hline
\end{tabular}

Note: the significance of difference as compared to values of fraction soluble in $0.5 \mathrm{M}$ acetic acid is signed by asterisks $* P \leq 0,05, * * P \leq 0.01$

The distribution of CMC molecules according to molecular mass in different fractions was investigated by PAGE in a step gradient porosity of gel. The electrophoretic plots and their quantitative interpretation are shown in Fig. 1 and Table 2. It was revealed that the molecular mass of CMC samples is widely extended from MDa to $10 \mathrm{kDa}$, though the main quantity of material is concentrated in 80-200 kDa range. Average molecular mass values do not reflect the real distribution of molecules according to molecular mass in a sample of CMC, as well as in other chitosans.

The results of the electrophoretic analysis also supports the opinion that fractionation of raw CMC by a differential solubilization at distinct $\mathrm{pH}$ values led to a redistribution of molecules between the fractions. The fraction soluble at $\mathrm{pH}$ 5.0-7.0 was enriched with molecules of higher molecular mass (from 230 to $75 \mathrm{kDa}$ ) and corresponded to about $70 \%$ of material, while the fraction soluble at $\mathrm{pH}$ 7.2-8.0 was

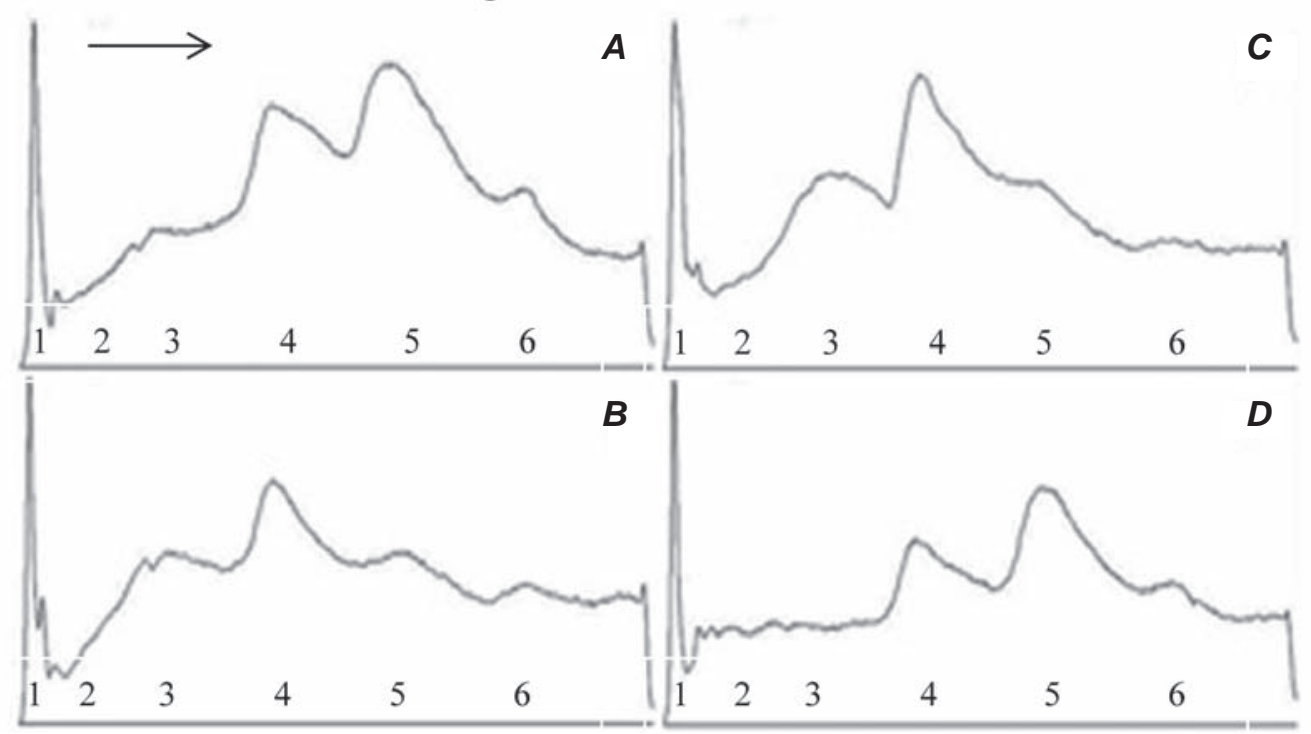

Fig. 1. Electrophoretic plots of CMC fractions. Electrophoresis was conducted in $\beta$-alanine-acetic acid buffer system, pH 4.5. Application of samples corresponds to peak 1, which contains melanin and insoluble chitosan particles not migrating in gel. Soluble fractions migrate to cathode $(\rightarrow)$. Designation of plot's images: $\boldsymbol{A}-C M C$ soluble in $0.5 \mathrm{M}$ acetic acid (raw CMC), $\boldsymbol{B}$ - fraction of CMC acetate soluble in $\mathrm{pH}$ 5.0-7.0 range; $\boldsymbol{C}$ - fraction of CMC glycolate soluble in $p H$ 5.0 -7.0 range; $\boldsymbol{D}$ - fraction of CMC soluble in $p H$ 7.0-8.6 range. Numbers of peaks are indicated on base line 
Table 2. Percentage distribution of material between electrophoretic bands in fractions of chitosanmelanin complex

\begin{tabular}{c|c|c|c|c|c}
\hline \multirow{2}{*}{$\begin{array}{c}\text { Digit of } \\
\text { electro- } \\
\text { phoretic } \\
\text { band }\end{array}$} & $\begin{array}{c}\text { Ranges of } \\
\text { molecular mass }\end{array}$ & $\begin{array}{c}\text { Soluble in 0.5 M } \\
\text { acetic acid }\end{array}$ & $\begin{array}{c}\text { Soluble in } \\
\text { pH 5.0-7.0 } \\
\text { acetate anion) }\end{array}$ & $\begin{array}{c}\text { Soluble in } \\
\text { pH 5.0-7.0 } \\
\text { (glycolate anion) }\end{array}$ & $\begin{array}{c}\text { Soluble in } \\
\text { pH 7.0-8.6 }\end{array}$ \\
\cline { 3 - 6 } 1 & No migration in gel & $4.89 \pm 0.60$ & $5.29 \pm 1.38$ & $6.20 \pm 0.87$ & $6.15 \pm 1.04$ \\
2 & $1 \mathrm{MDa}$ & $2.80 \pm 1.15$ & $3.20 \pm 0.87$ & $4.12 \pm 0.35$ & $5.43 \pm 0.65$ \\
3 & $1 \mathrm{MDa}-320 \mathrm{kDa}$ & $17.80 \pm 2.77$ & $35.10 \pm 4.67^{* * \uparrow}$ & $34.18 \pm 2.42^{* * \uparrow}$ & $21.92 \pm 2.42$ \\
4 & $230-75 \mathrm{kDa}$ & $32.70 \pm 3.46$ & $34.80 \pm 4.33$ & $36.70 \pm 2.60$ & $26.10 \pm 2.94 * \downarrow$ \\
5 & $65-30 \mathrm{kDa}$ & $34.81 \pm 4.67$ & $17.02 \pm 2.08^{* *} \downarrow$ & $15.20 \pm 1.38^{* *} \downarrow$ & $34.20 \pm 3.81$ \\
6 & $25-10 \mathrm{kDa}$ & $7.00 \pm 0.70$ & $4.59 \pm 0.60^{*} \downarrow$ & $3.60 \pm 0.60^{*} \downarrow$ & $6.20 \pm 0.87$ \\
Total & & 100.0 & 100.0 & 100.0 & 100.0 \\
\hline
\end{tabular}

Note. The content of material in bands is given in \%. Digit of bands corresponds to the number of peaks in fig.1. Composition of fractions is compared with the raw CMC soluble in $0.5 \mathrm{M}$ acetic acid. Significance of increase $(\uparrow)$ or decrease $(\downarrow)$ in content of material in bands is marked by asterisks: $* P<0.05,{ }^{* *} P<0,01(n=3)$

enriched with lower molecular mass material in 65$30 \mathrm{kDa}$ ranges.

The proposed method of isolation and fractionation of the CMC differs from published analogous methods in performance the deacetylation of chitomelanin directly without previous elimination of melanin. In similar methods, chitosan-melanin complex was obtained by recombination of purified chitosan with melanins of self or non-self origin $[16,20]$.

We suggest that the hydrolysis of chitin-melanin complex in $40 \% \mathrm{NaOH}$ retains the biological activity of product (e.g. blood clotting test, which is very sensitive to alteration) better than treatment with strong oxidants used for elimination of the melanin. Besides, in proposed method the raw CMC was fractionated by a differential solubilization at distinct $\mathrm{pH}$ values. Fractions soluble in higher $\mathrm{pH}$ values were enriched with lower molecular mass chitosan molecules which differ in biological activities from those of higher molecular mass. We also revealed that acidic counter anions which form a salt form of CMC are of importance in its biological properties. In particular, glycolic acid being stronger and more hydrophilic than acetic acid distinctly improved solubility and biological activity of CMC, e.g. in hemocoagulating and antimicrobial effect.

Studies of antimicrobial activity of CMC were performed at two values of $\mathrm{pH} 5.7 \pm 0.1$ and $7.0 \pm 0.1$, as it was shown that the $\mathrm{pH}$ value of the medium is of great importance for the antibacterial effect of chitosan [5, 6, 22]. This aspect is poorly investigated for insect chitosans and lack of data regarding the effect of $\mathrm{pH}$ upon the antifungal effect of the honeybee CMC supported the performance of experiments at chosen $\mathrm{pH}$ values.

The obtained results showed that the CMC and its fractions displayed the most prominent inhibiting activity towards $C$. albicans cells. A suppressing effect towards laboratory strain of $C$. albicans was achieved at $\mathrm{IC}_{50}=50 \mu \mathrm{g} / \mathrm{ml}$, and the glycolate salt of CMC was more active than the acetate one (Table 3). Besides, it was revealed that both salt forms of the $\mathrm{CMC}$ exhibited significantly higher inhibiting effect towards drug resistant (e.g. to clotrimazol) N 12 strain of $C$. albicans than towards a wild type drugsensitive one.

The candidacidal activities of the CMC at $\mathrm{pH} 5.8$ and 7.0 are compared in Fig. 2. The $\mathrm{IC}_{50}$ of $\mathrm{CMC}$ at $\mathrm{pH} 7.0$ was shown to be significantly higher, as compared at $\mathrm{pH} 5.8$, indicating a decrease in the $\mathrm{CMC}$ efficiency at neutral $\mathrm{pH}$. Apparently, that depends on the aggregation of CMC molecules in neutral medium, thus, diminishing the concentration of particles with a high positive charge that provides the antimicrobial effect.

The results of investigation of CMC antibacterial activity are shown in Table 4 . The bacteria exhibited lower sensitivity to the CMC action, thus, the concentration of the CMC was enhanced to 0.1-0.4 $\mathrm{mg} / \mathrm{ml}$ level in order to achieve more distinct inhibition of the metabolic activity in bacteria in the presence of the CMC. The effect of CMC was better expressed at $\mathrm{pH} 5.8$ in all studied bacteria. E. coli was 
Ta b le 3. Candidacidal activity of CMC towards drug-sensitive and drug-resistant C. albicans strains

\begin{tabular}{l|c|c|c}
\hline \multirow{2}{*}{\multicolumn{1}{c}{ Agent }} & \multirow{2}{*}{$\begin{array}{c}\text { Concentration of } \\
\text { agent, } \mathrm{mg} / \mathrm{ml}\end{array}$} & \multicolumn{2}{c}{$\begin{array}{c}\text { \% ratio of CFU number in experimental } \\
\text { probes relative to control }\end{array}$} \\
\cline { 3 - 4 } & & $\begin{array}{c}\text { C. albicans ATCC- } \\
885-655\end{array}$ & $\begin{array}{c}\text { C. albicans N 12 } \\
\text { (drug resistant) }\end{array}$ \\
\hline Control 0 h & 0 & $100.0 \pm 2.0$ & $100.0 \pm 2.0$ \\
Control 4 h & 0 & $159.5 \pm 9.0$ & $176.4 \pm 12.6$ \\
CMC fraction soluble & 0.05 & $67.3 \pm 8.1$ & $11.2 \pm 2.4$ \\
in pH 5.0-7.0, & 0.10 & $30.9 \pm 3.6$ & $8.8 \pm 2.1$ \\
acetate salt & 0.20 & $8.8 \pm 1.7$ & $1.8 \pm 0.9$ \\
CMC fraction soluble & 0.05 & $48.0 \pm 5.7$ & $10.4 \pm 1.7$ \\
in pH 5.0-7.0, & 0.10 & $12.8 \pm 3.1$ & $6.0 \pm 1.4$ \\
glycolate salt & 0.20 & $5.3 \pm 1.4$ & $3.2 \pm 0.9$ \\
\hline
\end{tabular}

Note: The number of CFU in the control at the start of incubation (control $0 \mathrm{~h}$ ) was accepted as $100 \%$. The difference in all experimental data compared to control $0 \mathrm{~h}$ value showed a high level of significance, $P<0.01$, $(n=3)$.

the most sensitive among three bacterial strains, and a significant inhibition was achieved at CMC concentration of $0.1 \mathrm{mg} / \mathrm{ml}$. St. aureus was distinctly inhibited at the CMC concentration of $0.2 \mathrm{mg} / \mathrm{ml}$. While $P$. aeruginosa revealed the highest resistance to the $\mathrm{CMC}$ being significantly suppressed at its concentration equal $0.4 \mathrm{mg} / \mathrm{ml}$ at $\mathrm{pH} 5,8$ and without a response at $\mathrm{pH}$ 7.0. The last was distinctly manifested at CMC concentration of about $1 \mathrm{mg} / \mathrm{ml}$ at which a lot of precipitated material appeared in the incubation medium.

The efficacy of CMC action towards studied microorganisms was demonstrated by a comparison of CMC concentrations providing half maximal inhibition effect $\mathrm{IC}_{50}$ (Fig. 2). $\mathrm{IC}_{50}$ were deduced from plots of the activity (\% ratio of inhibition relative to control) vs concentration of CMC (Table 4).

The obtained results clearly show that the antimicrobial activity of the CMC is $\mathrm{pH}$ dependent and it is manifested better at $\mathrm{pH}$ lower than 7.0-7.2 that is similar to other chitosans. It is known that the first event in the mechanisms of the antimicrobial action of chitosan is its binding with the negatively charged functional groups on cell surface. That leads to alteration in membrane permeability and a leakage of the vital components from cell cytoplasm [23, 24]. The efficiency of binding of the CMC with negatively charged cell surface, in turn, depends upon the value of chitosan's positive charge. The pKa value of chitosan of the marine crustaceans is in a range of 6.26.6 [6], in the medium at neutral $\mathrm{pH} 7$ or higher its charge is minimal and its binding with cell surfaces is markedly decreased. Besides, in alkaline media, chitosan molecules readily aggregate and produce an unstable colloid or precipitate dependently upon concentration. That leads to a decrease in actual concentration of active principle that becomes much less than in molecular dispersion of the chitosan solution.

However, in the conditions of poor solubility at $\mathrm{pH}$ 7.0, the CMC displays a diminished although distinct inhibiting activity towards fungi and most bacteria. Moreover, it was referred that crosslinked aerogels of chitosan used is the form of small water insoluble particles demonstrated high bactericidal effect towards E. coli and S. aureus [8]. This can be explained in the way that aggregated particles of the CMC exhibit the antimicrobial activity through absorption of the microorganisms on the surface of the particle with high positive charge that further destroys attached cell.

Specific microorganisms differ in their sensitivity to the CMC. The extent of damage depends on a quantity of bound chitosan with exposed anionic groups in different cell wall/cell membrane compounds (lipopolysaccharides, glycolipids, muramic acid, modified mannans, glucans etc.). Unfortunately, the nature of receptor(s) of chitosan in Candida $s p$. causing its high sensitivity to chitosan is poorly studied.

The role of melanin for the candidacidal activity of the CMC was investigated by comparing the inhibiting activity of pure melanin and CMC upon the growth of $C$. albicans cells. Melanin was obtained from washings water in a process of chitosan iso- 
Ta ble 4. Antibacterial activity of chitosan-melanin complex and its dependence on $\mathrm{pH}$ value of the medium

\begin{tabular}{|c|c|c|c|c|}
\hline \multirow{2}{*}{$\begin{array}{l}\text { Concentration of } \\
\text { agent, } \mathrm{mg} / \mathrm{ml}\end{array}$} & \multicolumn{2}{|c|}{ Medium pH 5.8} & \multicolumn{2}{|c|}{ Medium $\mathrm{pH} 7.0$} \\
\hline & OD $580 \mathrm{~nm}$ & $\begin{array}{l}\% \text { ratio relative } \\
\text { to control }\end{array}$ & OD $580 \mathrm{~nm}$ & $\begin{array}{l}\% \text { ratio relative } \\
\text { to control }\end{array}$ \\
\hline \multicolumn{5}{|c|}{ E. coli } \\
\hline 0 (control) & $0.60 \pm 0.05$ & $100.0 \pm 8.3$ & $0.89 \pm 0.06$ & $100.0 \pm 6.5$ \\
\hline 0.4 & $0.14 \pm 0.02 * *$ & $23.3 \pm 3.3$ & $0.26 \pm 0.02 * *$ & $29.2 \pm 1.9$ \\
\hline 0.2 & $0.15 \pm 0.02 * *$ & $25.0 \pm 3.3$ & $0.32 \pm 0.02 * *$ & $36.0 \pm 2.3$ \\
\hline 0.1 & $0.28 \pm 0.03^{* *}$ & $46.7 \pm 3.3$ & $0.72 \pm 0.05^{*}$ & $80.6 \pm 5.3$ \\
\hline \multicolumn{5}{|c|}{ St. aureus } \\
\hline 0 (control) & $0.74 \pm 0.05$ & $100.0 \pm 8.1$ & $0.89 \pm 0.07$ & $100.0 \pm 7.6$ \\
\hline 0.4 & $0.10 \pm 0.01^{* *}$ & $13.5 \pm 1.4$ & $0.37 \pm 0.03^{* *}$ & $41.6 \pm 3.2$ \\
\hline 0.2 & $0.19 \pm 0.02 * *$ & $25.7 \pm 2.7$ & $0.41 \pm 0.03^{* *}$ & $46.1 \pm 3.3$ \\
\hline 0.1 & $0.41 \pm 0.03^{* *}$ & $55.6 \pm 4.1$ & $0.79 \pm 0.06$ & $89.0 \pm 7.0$ \\
\hline \multicolumn{5}{|c|}{ Ps. aeruginosa } \\
\hline 0 (control) & $0.86 \pm 0.06$ & $100.0 \pm 8.0$ & $0.99 \pm 0.07$ & $100.0 \pm 7.1$ \\
\hline 0.4 & $0.24 \pm 0.02 * *$ & $27.9 \pm 2.0$ & $0.83 \pm 0.07 *$ & $83.8 \pm 7.1$ \\
\hline 0.2 & $0.54 \pm 0.04 * *$ & $62.8 \pm 4.4$ & $0.98 \pm 0.07$ & $99.0 \pm 7.1$ \\
\hline 0.1 & $0.65 \pm 0.04^{*}$ & $75.3 \pm 6.0$ & $0.97 \pm 0.07$ & $98.0 \pm 7.1$ \\
\hline
\end{tabular}

Note. The significance of inhibiting effect is indicated in columns of OD and marked by asterisks: $* P<0.05, * * P<0.01$, $(\mathrm{N}=3)$

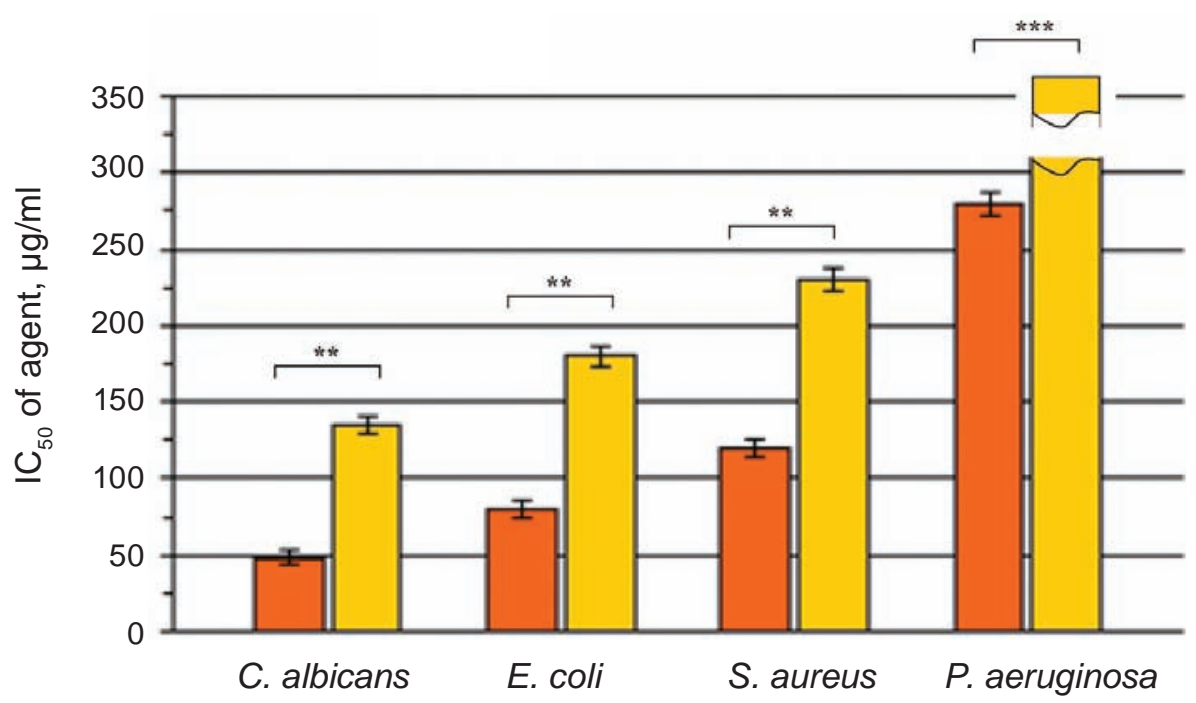

Fig. 2. $I C_{50}$ at the action of CMC towards studied microorganisms and its dependence on the $\mathrm{pH}$ of medium Designations. $\square-I C_{50}$ at $\mathrm{pH}$ 5.8; $\square-I C_{50}$ at $\mathrm{pH}$ 7.0. $I C_{50}$ of $P$. aeruginosa at $\mathrm{pH} 7.0$ was about $0.8 \pm 0.1 \mathrm{mg} /$ $\mathrm{ml}$, the subsequent column is interrupted and not corresponds to real size. ${ }^{*} P P<0.01,{ }^{* * *} P \leq 0.001$

lation. It was precipitated by acidification with $\mathrm{HCl}$ to the $\mathrm{pH}$ 2.5-3.0 and purified by repeated solubilization in alkaline and precipitation in acidic media. It was revealed that pure melanin showed very low inhibiting effect arresting Candida cells growth at $400 \mu \mathrm{g} / \mathrm{ml}$ concentration. At the same time, the $\mathrm{CMC}$ acetate showed a distinct candidacidal effect by reducing the number of viable cells to $70 \%$ of start value at $50 \mu \mathrm{g} / \mathrm{ml}$ concentration (Fig. 3). Thus, melanin possesses weak antimicrobial activity, it is 


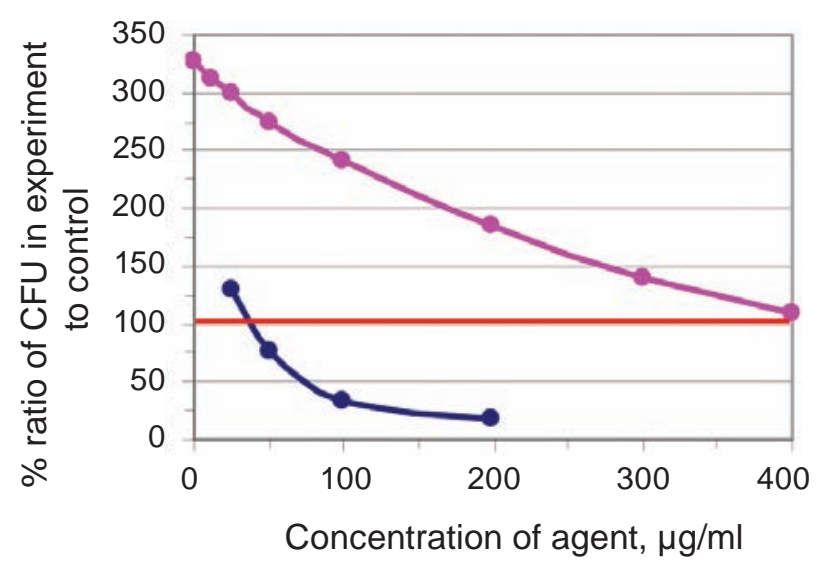

Fig. 3. Comparison of suppressor effect of CMC acetate fraction - soluble at $\mathrm{pH}$ 5.0-7.0 and melanin - towards C. albicans ATCC 885-655. Method of CFU was used with incubation in the medium with $\mathrm{pH} 5.6$, at $37^{\circ} \mathrm{C}$ for $6 \mathrm{~h}$. Red line at point 100 corresponds to the number of colonies in control at the start of incubation and accepted as 100\%

not harmful for bacteria, however, it is important in a support of the antimicrobial effect of the CMC.

A comparative study of the candidacidal effect towards drug resistant N12 strain of C. albicans of the CMC and some traditional antibiotics was performed using CFU method. As revealed, CMC-glycolate at $50 \mu \mathrm{g} / \mathrm{ml}$ concentration and $4 \mathrm{~h}$ incubation at $37^{\circ} \mathrm{C}$ caused a $50 \%$ decrease in number of viable yeast cells from the initial value that is close to that of the nystatin action exhibiting the analogous effect at $20 \mu \mathrm{g} / \mathrm{ml}$ concentration. Other antibacterial antibiotics (ampicillin, erythromycin, chloramphenicol, gentamycin) at $100 \mu \mathrm{g} / \mathrm{ml}$ concentration, did not show significant effect upon the growth of C. albicans cells.

Conclusion. The method of isolation of chitosan-melanin complex (CMC) from the honeybee corpses and its purification by a differential solubilization at distinct $\mathrm{pH}$ values were developed. The investigation of the antimicrobial activity of the obtained preparations revealed that CMC displayed the $\mathrm{pH}$ dependent inhibiting effect upon growth of microorganisms. It was better expressed at $\mathrm{pH} 5.9 \pm 0.1$ and diminished or negligible at $\mathrm{pH} 7.0 \pm 0.1$. The antimicrobial activity prevailed in the candidacidal effect when wild type Candida albicans was used as a target. However, drug resistant strain of C. albicans showed higher sensitivity than the wild type laboratory strain. The antibacterial effect of the CMC toward studied bacteria was moderate and it dimini- shed in order E. coli $>$ St. aureus $>$ Ps. aeruginosa . Thus, the honeybee CMC may be considered as a perspective agent in the medicinal compositions used for treatment of surface lesions caused by C. albicans.

Conflict of interest. Authors have completed the Unified Conflicts of Interest form at http://ukrbiochemjournal.org/wp-content/uploads/2018/12/ coi_disclosure.pdf and declare no conflict of interest.

Acknowledgements. We also thank the Association for Regional Cooperation in the Fields of Health, Science and Technology (RCOOP- HST Association) for support of research and a possibility to N. Manko to present the obtained results at the RECOOP-HST meeting. The help of Nataliya Finiuk, PhD, in statistical analysis of results is greatly appreciated.

Funding. This study was supported by Grant N III-3-17 (2017-2021) from National Academy of Sciences of Ukraine.

\section{ХІТОЗАН-МЕЛАНІНОВИЙ КОМПЛЕКС БДЖІЛ: ОДЕРЖАННЯ І ДОСЛІДЖЕННЯ ЙОГО ПРОТИМІКРОБНОЇ АКТИВНОСТІ}

\author{
М. Луичик', Н. Манько1, О. Громико ${ }^{2}$ \\ С. Тістечок ${ }^{2}$, М. Луиик(мл.) $)^{3}$, Р. Стойка ${ }^{1 凶}$
}

\footnotetext{
${ }^{1}$ Інститут біології клітини НАН України, Львів;

${ }^{2}$ Львівський національний університет імені Івана Франка, Україна;

${ }^{3}$ Львівський національний медичний університет імені Данила Галицького, Україна;

凶e-mail: stoika.rostyslav@gmail.com
}

Протимікробна активність хітозанів морських ракоподібних достатньо добре вивчено, i вони широко застосовуються в медицині. Однак хітозани комах у цьому аспекті вивчено значно гірше, хоч вони також можуть мати практичне значення. Метою цього дослідження було одержання та очистка хітозан-меланінового комплексу (ХМК) із підмору бджіл і дослідження його протимікробної активності. Для визначення протибактерійної активності застосовували МТТ-тест, протигрибкову активність стосовно Candida albicans визначали методом колонієутворювальних одиниць. Описано модифікований спосіб ізолювання і очистки ХМК, який відрізняється від відомих аналогів тим, що деацетилування хітин-меланінового 
комплексу проводили шляхом гідролізу 40\%-им розчином $\mathrm{NaOH}$ без попереднього видалення меланіну з подальшою очисткою ХМК шляхом диференціальної солюбілізації за певних значень рН. Протимікробна активність ХМК характеризувалася переважанням кандидоцидної дії, $\mathrm{IC}_{50}$ стосовно лабораторного штаму C. albicans становила 50 мкг/мл. Чутливість досліджуваних бактерій до дії ХМК знижувалась у такому порядку: E. coli > St. aureus > Ps. aeruginosa. За характером протимікробної дії ХМК із підмору бджіл можна вважати перспективним компонентом медичних композитів для лікування уражень, спричинених грибком C. albicans.

К л юч о в і с лов а: хітозан-меланіновий комплекс, підмор бджіл, МТТ-тест, протимікробна активність.

\section{References}

1. Muzzarelli R, Tarsi R, Filippini O, Giovanetti E, Biagini G, Varaldo PE. Antimicrobial properties of N-carboxybutyl chitosan. Antimicrob Agents Chemother. 1990; 34(10): 2019-2023.

2. Dai T, Tanaka M, Huang YY, Hamblin MR. Chitosan preparations for wounds and burns: antimicrobial and wound-healing effects. Expert Rev Anti Infect Ther. 2011; 9(7): 857-879.

3. Jayakumar R, Prabaharan M, Sudheesh Kumar PT, Nair SV, Tamura H. Biomaterials based on chitin and chitosan in wound dressing applications. Biotechnol Adv. 2011; 29(3): 322337.

4. Tikhonov VE, Stepnova EA, Babak VG, Yamskov IA, Palma-Guerrero J, Jansson HB, Lopez-Llorca LV, Salinas J, Gerasimenko DV, Avdienko ID, Varlamov VP. Bactericidal and antifungal activities of a low molecular weight chitosan and its N-/2(3)-(dodec-2-enyl) succinoyl/-derivatives. Carbohydr Polyme. 2006; 64(1): 66-72.

5. Kulikov SN, Tikhonov VE, Blagodatskikh IV, Bezrodnykh EA, Lopatin S, Khairullin R, Philippova Yu, Abramchuk S. Molecular weight and $\mathrm{pH}$ aspects of the efficacy of oligochitosan against methicillin-resistant Staphylococcus aureus (MRSA). Carbohydr Polym. 2012; 87(1): 545-550.

6. Blagodatskikh IV, Kulikov SN, Vyshivannaya OV, Bezrodnykh EA, Tikhonov VE. N-Reacetylated Oligochitosan: pH Dependence of Self-Assembly Properties and Antibacterial Activity. Biomacromolecules. 2017; 18(5): 14911498.

7. Holubnycha V, Kalinkevich O, Ivashchenko O, Pogorielov M. Antibacterial activity of in situ prepared chitosan/silver nanoparticles solution against methicillin-resistant strains of Staphylococcus aureus. Nanoscale Res Lett. 2018; 13(1): 71.

8. Radwan-Pragłowska J, Piątkowski M, Deineka V, Janus Ł, Korniienko V, Husak E, HolubnychaV, Liubchak I, Zhurba V, Sierakowska A, Pogorielov M, Bogdał D. Chitosan-based bioactive hemostatic agents with antibacterial properties-synthesis and characterization. Molecules. 2019; 24(14): 2629.

9. Nemtsev SV, Zueva OIu, Khismatullin MR, Albulov AI, Varlamov VP. Isolation of chitin and chitosan from honey bees. Prikl Biokhim Mikrobiol. 2004; 40(1): 46-50. (In Russian).

10. Pat. Ru 2382 051, Int.Cl. C08B 37/00. Method of obtaining of chitosan-melanin complex from bee corpses/ Selionova MI, Pogarskaya NI. Publ. 20.02.2010, N 5. (In Russian).

11. Draczynski Z. Honeybee corpses as an available source of chitin. J Appl Polym Sci. 2008; 109(3): 1974-1981.

12. Marei NH, Abd El-Samie E, Salah T, Saad GR, Elwahy AHM. Isolation and characterization of chitosan from different local insects in Egypt. Int J Biol Macromol. 2016; 82: 871-877.

13. Tyliszczak B, Drabczyk A, Kudłacik S, BialikWas K, Sobczak-Kupiec A. Beetosan/chitosan from bees - preparation and properties. Int J Adv Sci Eng Technol. 2016; 4(2): 118-120.

14. Bakulin AV, Veleshko IYe, Rumyantseva YeV, Levov AN, Burmistrova LA, Kurchenko VP, Khismatullin RG, Varlamov VP, Krivtsov NI. Production of chitin-melanin complexes from Apis mellifera and studying the opportunity of their usage as radionuclide sorbents. Dokl RAAS. 2011; (5): 48-51. (In Russian).

15. Tyliszczak B, Drabczyk A, Kudłacik S. Comparison of hydrogels based on commercial chitosan and beetosan ${ }^{\circledR}$ containing nanosilver. Molecules. 2016; 22(1): 61.

16. Tyliszczak B, Kudlacik-Kramarczyk S, Drabczyk A, Bogucki R, Olejnik E, Kinasiewicz J, Gląb M. Hydrogels containing caffeine and based on Beetosan - proecological chitosan preparation, characterization, and in vitro 
cytotoxicity. Int J Polym Mater Polym Biomater. 2019; 68(15): 931-935.

17. Tyliszczak B, Drabczyk A, KudłacikKramarczyk S, Grabowska B, Kędzierska M. Physicochemical properties and cytotoxicity of hydrogels based on Beetosan ${ }^{\circledR}$ containing sage and bee pollen. Acta Biochim Pol. 2017; 64(4): 709-712.

18. Lootsik MD, Bilyy RO, Lutsyk MM, Stoika RS. Preparation of chitosan with high blood clotting activity and its hemostatic potential assessment. Biotechnol Acta. 2015; 8(6): 32-41.

19. Lootsik MD, Bilyy RO, Lutsyk MM, Manko NO, Navytka SA, Kutsiaba VI, Stoika RS. Honeybee (Apis mellifera) chitosan: purification, heterogeneity and hemocoagulation activity. Biotechnol Acta. 2016; 9(6): 39-49.

20. Walencka E, Rózalska S, Sadowska B, Rózalska B. The influence of Lactobacillus acidophilus-derived surfactants on staphylococcal adhesion and biofilm formation. Folia Microbiol (Praha). 2008; 53(1): 61-66.

21. Grela E, Kozłowska J, Grabowiecka A. Current methodology of MTT assay in bacteria - A review. Acta Histochem. 2018; 120(4): 303-311.

22. Kulikov SN, Tikhonov VE, Bezrodnykh EA, Lopatin SA, Varlamov VP. Comparative evaluation of antimicrobial activity of oligochitosans against Klebsiella pneumoniae. Russ J Bioorg Chem. 2015; 41(1): 57-62. (In Russian).

23. Raafat D, von Bargen K, Haas A, Sahl HG. Insights into the mode of action of chitosan as an antibacterial compound. Appl Environ Microbiol. 2008; 74(12): 3764-3773.

24. Peña A, Sánchez NS, Calahorra M. Effects of chitosan on Candida albicans: conditions for its antifungal activity. Biomed Res Int. 2013; 2013: 527549 . 